\title{
Synthesis, Characterization, and Biological Studies of In Vitro Antibacterial, and Cytotoxic Activities of Norfloxacin Based Square Pyramidal Copper(II) Complexes
}

\author{
Divyang H. Gandhi ${ }^{1}{ }^{(D)}$, Bhupesh S. Bhatt ${ }^{2, *(D)}$, Keyur D. Bhatt ${ }^{3(\mathbb{C}}$ \\ C. U. Shah University, Wadhwancity-363035, Gujarat, India \\ Department of Chemistry, Sardar Patel University, Vallabh Vidyanagar-388 120, Gujarat, India \\ Department of Chemistry, Ganpat University, Kherva-384012, Gujarat \\ Correspondence: bhupeshbhatt31@gmail.com; bs_bhatt@spuvvn.edu;
}

Received: 8.12.2020; Revised: 3.01.2021; Accepted: 4.01.2021; Published: 6.01.2021

\begin{abstract}
The substantial increase in copper-containing complexes' research to treat bacterial infections encouraged us to synthesize fluoroquinolone drug norfloxacin (NFLH) based copper complexes. In this work, we presented the synthesis of mixed ligand $\mathrm{Cu}$ complexes with the basic structural formula $\left[\mathrm{Cu}(\mathrm{NFL})\left(\mathrm{A}_{1}\right) \mathrm{Cl}\right]$, where $\mathrm{An}$ is isatin-based ligands. The characterization of compounds by Mass, FTIR, UV-Vis spectroscopy, magnetic measurement, and conductivity measurement revealed the neutral nature and square pyramidal geometry of all the copper compounds. The biological screening of compounds displayed the potent bacteriostatic activity of copper compounds compare with the standard drug against four medically significant pathogens. The in vitro cytotoxic activity of copper compounds was checked on artemia cyst. The biological studies data are promising for their application as medicinally important compounds for future perspective.
\end{abstract}

Keywords: fluoroquinolone drug; spectroscopy; bacteriostatic activity; cytotoxicity.

(C) 2020 by the authors. This article is an open-access article distributed under the terms and conditions of the Creative Commons Attribution (CC BY) license (https://creativecommons.org/licenses/by/4.0/).

\section{Introduction}

The success of cisplatin has influenced the anticancer drug discovery methodologies and open up a new era for bioinorganic researchers to study and develop metal-based drugs [1-3]. The medicinal role of metal-based compounds has been widely explored $[4,5]$. In metalbased drugs, the metal-ligands space configuration allows the molecule to interact with a definite molecular target, enriched by modifications of the ligand structure. Also, the metal complexes are involved in biological redox chemistry and can interact with bio-molecules. The notable point is the practice of copper-based biologically active complexes for these studies [613]. Copper is involved in numerous physiological cellular processes and cytotoxic; hence the copper-based compounds were found promising particularly $[14,15]$. A recent study found that copper complex may selectively inhibit tumor cell growth and induce apoptosis through the mitochondrial apoptotic pathway [16], down-regulation of anti-apoptosis proteins [17], or via accumulation of ROS [18, 19]. Recent studies indicated that copper-based Schiff base compounds exhibited better antitumor and antibacterial activities than ligands. The copper complexes are also known to possess good antibacterial activity [20-23]. 
Norfloxacin is a xenobiotic broad-spectrum bactericidal quinolone monocarboxylic acid, which functions as a DNA synthesis inhibitor through binding with DNA gyrase. The binding of norfloxacin and subsequent alteration in the normal function of DNA gyrase has been creating enormous interest among medicinal researchers to explore antibacterial and antitumor activities of norfloxacin based compounds [24, 25]. So, we synthesized norfloxacin based mixed ligand copper complexes with isatin ligands. The neutral $\mathrm{Cu}$ (II) complexes were characterized by mass spectrometry, FT-IR, electronic spectroscopy, conductivity, and magnetic moment measurement. Also, the drug-based compounds were studied for antibacterial and cytotoxic activities.

\section{Materials and Methods}

\subsection{Chemicals and materials.}

Analytical grade chemicals and solvents were used for all the studies. Isatin, $p$-chloro aniline, $m$-chloro aniline, $o$-chloro aniline, $p$-bromo aniline, $m$-nitro aniline, $p$-nitro aniline, $p$ hydroxybenzoic acid, $p$-methoxy aniline, and $p$-toluidine were procured from Sigma Aldrich (India). IR spectra were obtained on an FT-IR Shimadzu instrument in the range $4000-400 \mathrm{~cm}^{-1}$, and the sample was prepared as $\mathrm{KBr}$ pellets. The electronic spectra were obtained on a UV-160A, Shimadzu (Japan) UV-visible spectrophotometer. The Gouy's balance was used for magnetic moment measurement.

\subsection{Synthesis.}

The ligands (isatin derivatives) were synthesized according to the reported procedure [26]. The copper complexes $\left[\mathrm{Cu}(\mathrm{NFL})\left(\mathrm{A}^{\mathrm{n}}\right) \mathrm{Cl}\right.$ ] were synthesized by stirring $\mathrm{CuCl}_{2} \cdot 2 \mathrm{H}_{2} \mathrm{O}(1.5$ $\mathrm{mmol})$ and ligand $\left(\mathrm{A}_{\mathrm{n}}\right)(1.5 \mathrm{mmol})$ solution in an RBF for 10 minutes. This is followed by adding the norfloxacin (NFLH) solution $(1.5 \mathrm{mmol}$, methanolic solution neutralized by sodium methoxide) at $\mathrm{pH} \sim 6.2$. The reaction mixture was refluxed on a steam bath for $1.5 \mathrm{~h}$. The completion of the reaction was monitored on TLC. The reaction mass was concentrated under vacuum, filtered, and washed by dichloromethane. The air drying of reaction mass yielded an amorphous product of light brown color (Scheme 1).

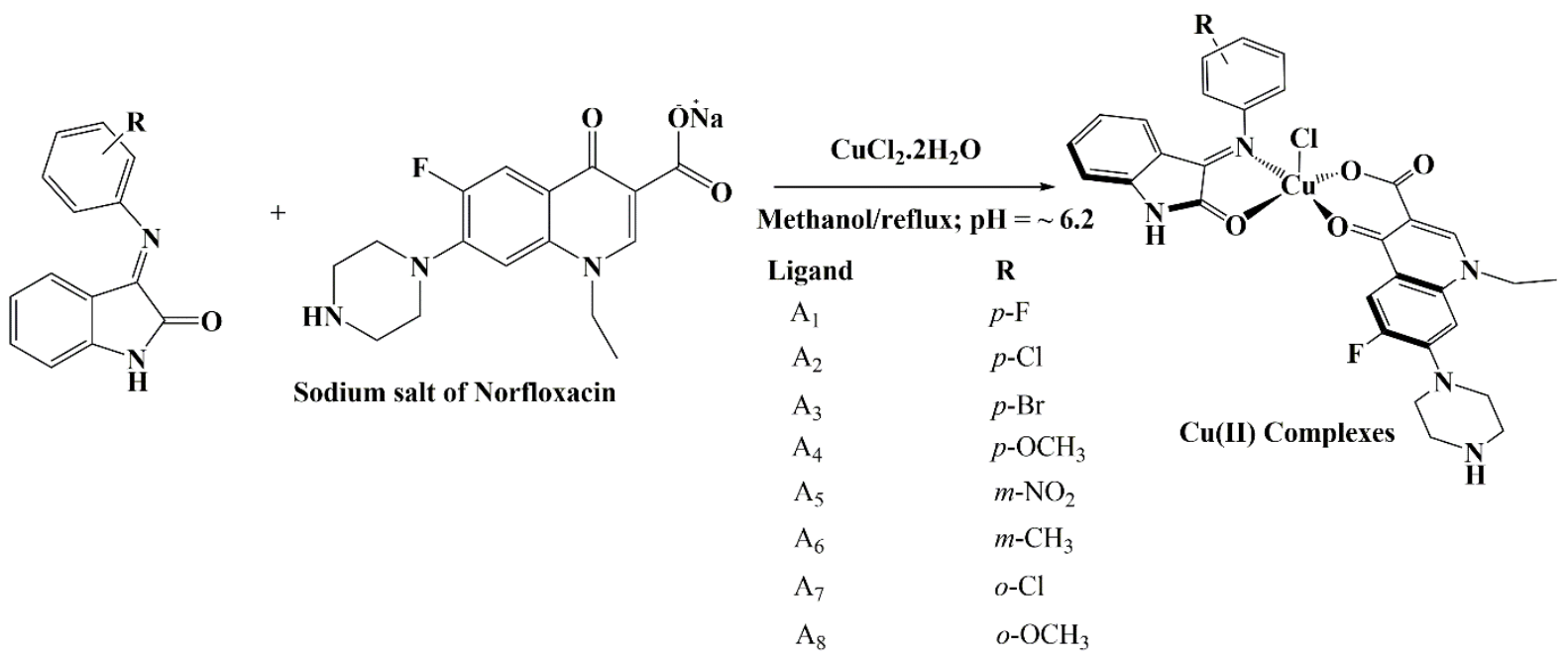

Scheme 1. Reaction scheme for synthesis of metal complexes. 


\subsection{In vitro antibacterial assay.}

The bacteriostatic activity of the metal salt, norfloxacin (standard), and complexes were screened in vitro against two $\mathrm{Gram}^{(+\mathrm{ve})}$ : Bacillus subtilis, Staphylococcus aureus microorganisms; and two Gram ${ }^{(-v e)}$ : Escherichia coli, Serratia marcescens; in terms of MIC (minimum inhibitory concentration) by using reported procedure [27]. The double dilution method was used to incubate bacterial culture in Luria Broth at $37 \mathrm{oC}$, resulting in turbid solution after $18 \mathrm{~h}$. The clear solution is an indication of the inhibitory effect shown by the compounds under study.

\subsection{Brine shrimp lethality assay.}

According to the literature, the assay was performed in which the hatching of artemia cyst eggs in artificial seawater for 2 days produced nauplii. A stock solution of complex (concentration $10 \mathrm{mg} / 10 \mathrm{~mL}$ DMSO) was transferred to vials so that the final concentration of complexes in solution remains $2,4,8,12,16$, and $20 \mu \mathrm{g} \mathrm{mL}^{-1}$. The 10 nauplii were added to a total volume of $2.5 \mathrm{~mL}$ per vial with seawater. The mortality rate of nauplii was determined after $24 \mathrm{~h}$. The log [complex] was plotted against the \%mortality of nauplii, which gives the LC 50 value [28].

\section{Results and Discussion}

\subsection{Characterization.}

The copper compounds were characterized by diverse spectrometric (Mass, FT-IR, electronic spectra) and analytical (magnetic moment and conductivity measurement) techniques. The Physico-chemical parameters are provided in Table 1. The estimation of metal content was performed by the spectrophotometric method [29]. The spectrophotometry titrimetric data supports the calculated copper percentage. The norfloxacin pyridine ring $v(\mathrm{C}=\mathrm{O})$ band shifts from $1730 \mathrm{~cm}^{-1}$ to $1615-1632 \mathrm{~cm}^{-1}$ in the infrared spectra of complexes, which agrees to the pyridine carbonyl oxygen participation as coordinating atom (Table 2). The difference between the asymmetric and symmetric stretching frequency of - $\mathrm{COO}(\Delta v)$ for the complexes is obtained $\sim 200 \mathrm{~cm}^{-1}$. The difference of about $200 \mathrm{~cm}^{-1}$ indicates unidentate coordination of copper with the carboxylic oxygen atom. The additional bands in the range $542-552 \mathrm{~cm}^{-1}$ and $515-523 \mathrm{~cm}^{-1}$ in the infrared spectra of complexes are assigned to $v(\mathrm{M}-\mathrm{N})$ and $v(\mathrm{M}-\mathrm{O})$, respectively. The mass spectrum of complex-1 displayed a molecular ion peak at $686.7 \mathrm{~m} / \mathrm{z}$ (Figure 1).

Table 1. Physical characterization data of complexes.

\begin{tabular}{|c|c|c|c|c|c|c|c|}
\hline \multirow[b]{3}{*}{ Complexes } & \multirow[b]{3}{*}{ Empirical formula } & \multirow{3}{*}{$\begin{array}{l}\text { Molecula } \\
\text { r weight }\end{array}$} & \multirow{2}{*}{\multicolumn{2}{|c|}{$\% \mathrm{Cu}$}} & \multirow{3}{*}{$\begin{array}{l}\text { m.p. } \\
{ }^{\circ} \mathrm{C}\end{array}$} & \multirow{3}{*}{$\begin{array}{l}\mu_{\text {eff }} \\
/ \text { B.M. }\end{array}$} & \multirow{3}{*}{$\begin{array}{l}\text { Molar } \\
\text { conductivity/ } \\
\mu \mathrm{S} \mathrm{cm} \text { cm }^{-1}\end{array}$} \\
\hline & & & & & & & \\
\hline & & & Theoretical & Experimental & & & \\
\hline$\left[\mathrm{Cu}(\mathrm{NFL})\left(\mathrm{A}^{1}\right) \mathrm{Cl}\right](1)$ & $\mathrm{C}_{32} \mathrm{H}_{32} \mathrm{ClCuF}_{2} \mathrm{~N}_{5} \mathrm{O}_{4}$ & 687.62 & 9.24 & 8.99 & 246 & 1.79 & 24.0 \\
\hline$\left[\mathrm{Cu}(\mathrm{NFL})\left(\mathrm{A}^{2}\right) \mathrm{Cl}\right](2)$ & $\mathrm{C}_{32} \mathrm{H}_{32} \mathrm{Cl}_{2} \mathrm{CuFN}_{5} \mathrm{O}_{4}$ & 704.08 & 9.03 & 8.71 & 248 & 1.80 & 23.6 \\
\hline$\left[\mathrm{Cu}(\mathrm{NFL})\left(\mathrm{A}^{3}\right) \mathrm{Cl}\right](3)$ & $\mathrm{C}_{32} \mathrm{H}_{32} \mathrm{BrClCuFN}_{5} \mathrm{O}_{4}$ & 748.53 & 8.49 & 8.26 & $>250$ & 1.85 & 23.8 \\
\hline$\left[\mathrm{Cu}(\mathrm{NFL})\left(\mathrm{A}^{4}\right) \mathrm{Cl}\right](4)$ & $\mathrm{C}_{33} \mathrm{H}_{35} \mathrm{Cl}_{2} \mathrm{CuFN}_{5} \mathrm{O}_{5}$ & 699.66 & 9.08 & 8.78 & $>250$ & 1.82 & 22.5 \\
\hline$\left[\mathrm{Cu}(\mathrm{NFL})\left(\mathrm{A}^{5}\right) \mathrm{Cl}\right](5)$ & $\mathrm{C}_{32} \mathrm{H}_{32} \mathrm{ClCuFN}_{6} \mathrm{O}_{6}$ & 714.63 & 8.89 & 8.57 & 241 & 1.78 & 23.5 \\
\hline$\left[\mathrm{Cu}(\mathrm{NFL})\left(\mathrm{A}^{6}\right) \mathrm{Cl}\right](6)$ & $\mathrm{C}_{33} \mathrm{H}_{35} \mathrm{ClCuFN}_{5} \mathrm{O}_{4}$ & 683.66 & 9.29 & 9.02 & 245 & 1.76 & 22.9 \\
\hline$\left[\mathrm{Cu}(\mathrm{NFL})\left(\mathrm{A}^{7}\right) \mathrm{Cl}\right](7)$ & $\mathrm{C}_{32} \mathrm{H}_{32} \mathrm{Cl}_{2} \mathrm{CuFN}_{5} \mathrm{O}_{4}$ & 704.08 & 9.03 & 8.75 & 242 & 1.86 & 21.8 \\
\hline$/\left[\mathrm{Cu}(\mathrm{NFL})\left(\mathrm{A}^{8}\right) \mathrm{Cl}\right](8)$ & $\mathrm{C}_{33} \mathrm{H}_{35} \mathrm{Cl}_{2} \mathrm{CuFN}_{5} \mathrm{O}_{5}$ & 699.66 & 9.08 & 8.84 & $>250$ & 1.89 & 21.4 \\
\hline
\end{tabular}


The different $\mathrm{m} / \mathrm{z}$ observed at 368.1 and 318 are assigned to norfloxacin and isatin ligands fragments, respectively. The $\mu_{\text {eff }}$ (magnetic moment value) of complexes is observed in a 1.76-1.89 BM (Table 1), demonstrating an unpaired electron to the $\mathrm{Cu}^{+2}$ in complexes.

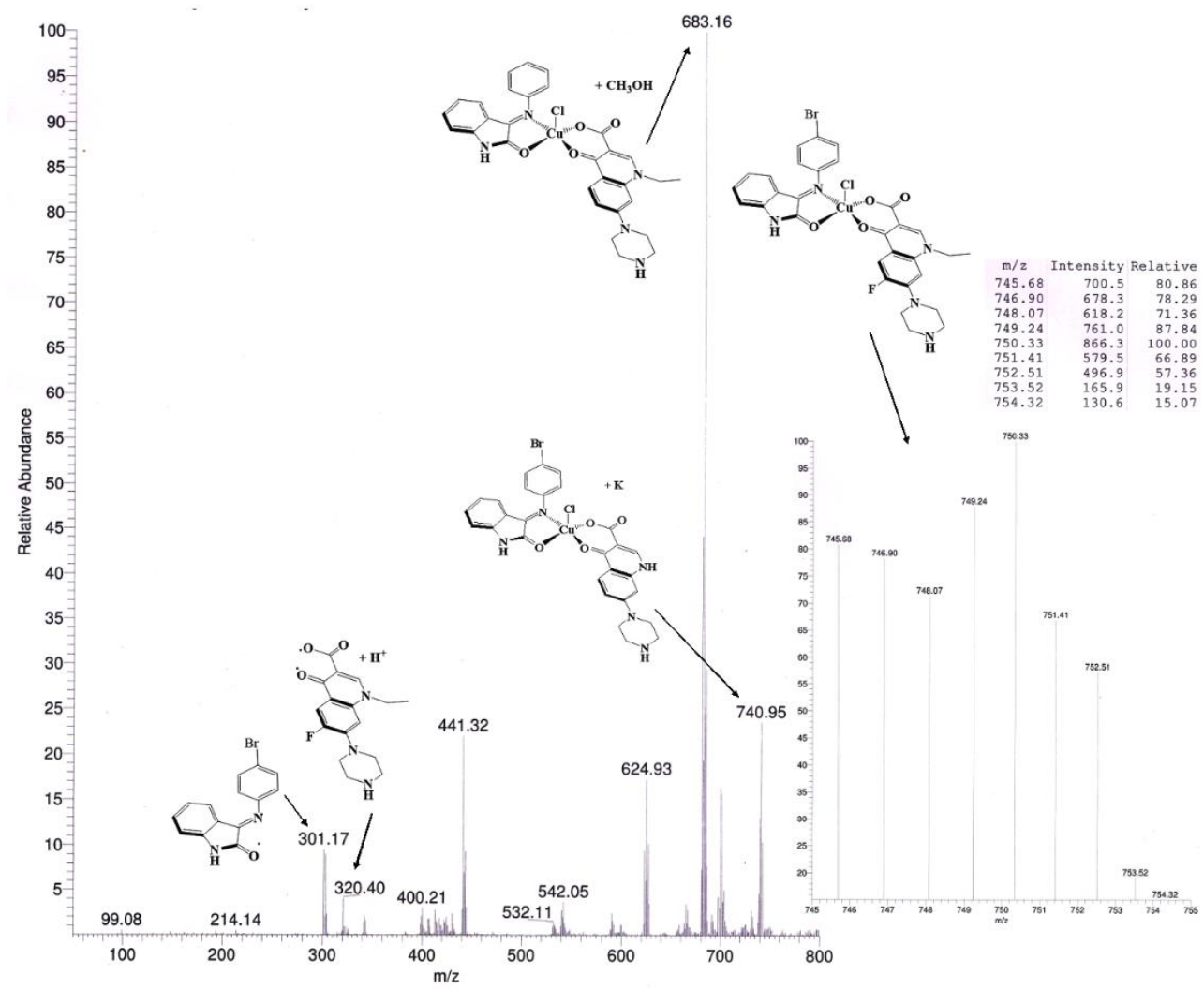

Figure 1. Mass spectra of complex -1 .

Table 2. IR spectra data.

\begin{tabular}{|c|c|c|c|c|c|c|}
\hline Complexes & $\begin{array}{c}\mathrm{v}(\mathrm{C}=\mathbf{O}) \text { pyridone } \\
/ \mathrm{cm}^{-1}\end{array}$ & $\begin{array}{c}\mathbf{v}(\mathrm{COO})_{\text {as }} \\
/ \mathrm{cm}^{-1}\end{array}$ & $\begin{array}{c}v(\mathrm{COO})_{\mathrm{s}} \\
/ \mathrm{cm}^{-1}\end{array}$ & $\begin{array}{c}\Delta v \\
/ \mathbf{c m}^{-1}\end{array}$ & $\begin{array}{c}\mathbf{v}(\mathbf{M}-\mathbf{N}) \\
/ \mathrm{cm}^{-1}\end{array}$ & $\underset{1}{\mathrm{v}(\mathrm{M}-\mathrm{O}) / \mathrm{cm}^{-}}$ \\
\hline Norfloxacin & 1730 & 1642 & 1336 & 306 & & - \\
\hline 1 & 1632 & 1561 & 1356 & 205 & 548 & 523 \\
\hline 2 & 1622 & 1572 & 1371 & 201 & 552 & 522 \\
\hline 3 & 1628 & 1560 & 1358 & 202 & 543 & 518 \\
\hline 4 & 1625 & 1569 & 1372 & 197 & 546 & 520 \\
\hline 5 & 1620 & 1572 & 1363 & 209 & 542 & 516 \\
\hline 6 & 1615 & 1570 & 1365 & 205 & 551 & 517 \\
\hline 7 & 1627 & 1568 & 1368 & 200 & 550 & 522 \\
\hline 8 & 1621 & 1562 & 1363 & 199 & 548 & 515 \\
\hline
\end{tabular}

3.2. In vitro antibacterial activity.

The drug resistance acquired among pathogenic bacteria is a matter of concern globally. This problem has stimulated the research to discover antibacterial agents that may have an alternate mechanism of action. The metal chelation of the drug could be a synthetic alternative for such a purpose. So we studied the bacteriostatic activity of norfloxacin based $\mathrm{Cu}(\mathrm{II})$ complexes in terms of MIC against two gram(+ve), and two gram(-ve) pathogens. In vitro antibacterial activity results show that all the metal complexes have exceptionally well potency than metal salt. Some complexes have more potency than norfloxacin (standard) against all tested pathogens (Table 3). Among all, the complex 1 bearing electron-withdrawing $\mathrm{F}$ atom 
shows very good potency against all the microorganisms. Tweedy's chelation theory may be applicable for such a higher potency of metal complexes, which explains that chelation results in $\pi$ - electrons delocalization over the whole ring. The sharing of $\mathrm{Cu}^{+2}$ charge with the orbital of ligand (orbital overlap) reduces the polarity, which increases the lipophilic nature of complexes [30]. This facilitates the complex's penetration into lipid membranes and results in improved potency.

Table 3. Biological activities data of metal complexes.

\begin{tabular}{l|c|c|c|c|c}
\multirow{2}{*}{ Compounds } & \multicolumn{4}{|c|}{ Antibacterial activity (MIC, $\boldsymbol{\mu M})$} & \multirow{2}{*}{ Cytotoxic activity (LC50, $\boldsymbol{\mu M}$ ) } \\
\cline { 2 - 5 } & \multicolumn{2}{|c|}{ Gram-positive } & \multicolumn{2}{c}{ Gram-negative } & \\
\cline { 2 - 5 } & S. aureus & B. subtilis & S. marcescens & $\boldsymbol{E}$. coli & \\
\hline $\mathrm{CuCl}_{2} \cdot 2 \mathrm{H}_{2} \mathrm{O}$ & 2698.0 & 2815.0 & 2756.0 & 3402.0 & - \\
\hline Norfloxacin & 2.5 & 2.5 & 4.1 & 2.8 & 7.2 \\
\hline 1 & 2.4 & 2.1 & 3.9 & 2.5 & 7.9 \\
\hline 2 & 2.5 & 2.2 & 4.2 & 2.5 & 8.9 \\
\hline 3 & 2.7 & 2.8 & 4.5 & 2.6 & 10.5 \\
\hline 4 & 2.9 & 3.0 & 4.5 & 2.7 & 8.2 \\
\hline 5 & 2.6 & 2.4 & 4.0 & 2.6 & 11.1 \\
\hline 6 & 3.0 & 3.2 & 5.0 & 3.5 & 8.1 \\
\hline 7 & 2.5 & 2.3 & 4.2 & 2.5 & 11.5
\end{tabular}

\subsection{Cytotoxic activity.}

Brine shrimp lethality bioassay cytotoxicity test is extensively used for screening of toxicity of a wide range of natural and synthetic materials. It's a preliminary toxicity assay for further investigations on higher animal models [31]. The cytotoxicity data (LC50 values) are revealed in Table 3. The LC 50 data demonstrates the potent cytotoxic nature of complexes. Complexes 1, 2, 5, and 7 are more cytotoxic than rest complexes. Complexes 6 and 8 are the least cytotoxic in nature.

\section{Conclusions}

The norfloxacin based $\mathrm{Cu}$ (II) complexes of isatin derivatives were synthesized and characterized by various analytical and spectroscopic techniques. The shift in norfloxacin infrared frequencies recommends the pyridine ring and $\mathrm{COO}$ functional group's oxygen atom as the coordinating atoms. The presence of an additional $v(\mathrm{M}-\mathrm{N})$ and $v(\mathrm{M}-\mathrm{O})$ infrared bands proposes coordination of amide $\mathrm{O}$ atom and $\mathrm{C}=\mathrm{N} \mathrm{N}$ atoms of isatin ligand as the coordinating units. The magnetic moment estimation recommends the presence of an unpaired electron with $\mathrm{Cu}^{+2}$ ion, and conductivity estimation suggests the non-electrolytic nature of complexes. The $\mathrm{UV}$-vis. spectrophotometry proposes the square pyramidal geometry of ligands around the metal ion. The complexes were screened for antibacterial and cytotoxicity. The MIC data reveal that some complexes are more potent bacteriostatic agents than standard drug norfloxacin, with an increase in lipophilicity due to chelation could be a probable reason, which increases the permeability of complexes. The $\mathrm{LC}_{50}$ values evaluated by brine shrimp lethality bioassay proposes metal complexes potent cytotoxic nature. 


\title{
Funding
}

This research received no external funding.

\section{Acknowledgments}

\begin{abstract}
The authors are thankful to the authority of C. U. Shah University for providing the necessary research facility and giving permission to carry out the research work.
\end{abstract}

\section{Conflicts of Interest}

The authors declare no conflict of interest.

\section{References}

1. Imberti, C.; Zhang, P.; Huang, H.; Sadler, P.J. New designs for phototherapeutic transition metal complexes. Angewandte Chemie 2020, 132, 61-73, https://doi.org/10.1002/anie.201905171.

2. Allardyce, C.S.; Dyson, P.J. Metal-based drugs that break the rules. Dalton transactions 2016, 45, 32013209, https://doi.org/10.1039/C5DT03919C.

3. Harringer, S.; Happl, B.; Ozenil, M.; Kast, C.; Hejl, M.; Wernitznig, D.; Legin, A.; Schweikert, A.; Gajic, N.; Roller, A. Synthesis, Modification, and Biological Evaluation of a Library of Novel Water-Soluble Thiopyridone-Based Organometallic Complexes, and Their Unexpected (Biological) Behavior. ChemistryA European Journal 2020, https://doi.org/10.1002/chem.201905546.

4. Pires, A.S.; Batista, J.; Murtinho, D.; Nogueira, C.; Karamysheva, A.; Luísa Ramos, M.; Milne, B.F.; Tavares, N.T.; Gonçalves, J.; Gonçalves, A.C. Synthesis, Characterization and Evaluation of the Antibacterial and Antitumor Activity of HalogenatedSalen Copper (II) Complexes derived from Camphoric Acid. Applied Organometallic Chemistry 2020, 34, https://doi.org/10.1002/aoc.5569.

5. Zhang, S.; Yao, X.; Watkins, N.H.; Rose, P.K.; Caruso, S.R.; Day, C.S.; Bierbach, U. Discovery of a Chiral DNA-Targeted Platinum-Acridine Agent with Potent Enantioselective Anticancer Activity. Angewandte Chemie International Edition 2020, 59, 21965-21970, https://doi.org/10.1002/anie.202009983.

6. Tisato, F.; Marzano, C.; Porchia, M.; Pellei, M.; Santini, C. Copper in diseases and treatments, and copperbased anticancer strategies. Medicinal research reviews 2010, 30, 708-749, https://doi.org/10.1002/med.20174.

7. MacLean, L.; Karcz, D.; Jenkins, H.; McClean, S.; Devereux, M.; Howe, O.; Pereira, M.D.; May, N.V.; Enyedy, É.A.; Creaven, B.S. Copper (II) complexes of coumarin-derived Schiff base ligands: Pro-or antioxidant activity in MCF-7 cells? Journal of inorganic biochemistry 2019, 197, https://doi.org/10.1016/j.jinorgbio.2019.110702.

8. Parsa, F.G.; Feizi, M.A.H.; Safaralizadeh, R.; Hosseini-Yazdi, S.A.; Mahdavi, M. Molecular mechanisms of apoptosis induction in K562 and KG1a leukemia cells by a water-soluble copper (II) thiosemicarbazone complex. Journal of Biological Inorganic Chemistry: JBIC: a Publication of the Society of Biological Inorganic Chemistry 2020, 25, 383-394, https://doi.org/10.1007/s00775-020-01769-0.

9. Reheman, D.; Zhao, J.; Guan, S.; Xu, G.-C.; Li, Y.-J.; Sun, S.-R. Apoptotic effect of novel pyrazolone-based derivative [Cu (PMPP-SAL)(EtOH)] on HeLa cells and its mechanism. Scientific Reports 2020, 10, 1-12, https://doi.org/10.1038/s41598-020-75173-8.

10. Hassan, H.M. Synthesis and evaluation of antimicrobial and cytotoxic activities of some Mannich bases bearing amino acid units and their copper complexes. Biointerface Research in Applied Chemistry 2012, 2.

11. Dimitrijević, J.; Arsenijević, A.N.; Milovanović, M.Z.; Arsenijević, N.N.; Milovanović, J.Z.; Stanković, A.S.; Bukonjić, A.M.; Tomović, D.L.; Ratković, Z.R.; Potočňḱ, I. Synthesis, characterization and cytotoxic activity of binuclear copper (II)-complexes with some S-isoalkyl derivatives of thiosalicylic acid. Crystal structure of the binuclear copper (II)-complex with S-isopropyl derivative of thiosalicylic acid. Journal of Inorganic Biochemistry 2020, 208, https://doi.org/10.1016/j.jinorgbio.2020.111078.

12. Carcelli, M.; Tegoni, M.; Bartoli, J.; Marzano, C.; Pelosi, G.; Salvalaio, M.; Rogolino, D.; Gandin, V. In vitro and in vivo anticancer activity of tridentate thiosemicarbazone copper complexes: Unravelling an unexplored pharmacological target. European Journal of Medicinal Chemistry 2020, 194, https://doi.org/10.1016/j.ejmech.2020.112266.

13. Bukonjić, A.M.; Tomović, D.L.; Stanković, A.S.; Jevtić, V.V.; Ratković, Z.R.; Bogojeski, J.V.; Milovanović, J.Z.; Đorđević, D.B.; Arsenijević, A.N.; Milovanović, M.Z. Synthesis, characterization and biological activity of copper (II) complexes with ligands derived from $\beta$-amino acids. Transition Metal Chemistry 2019, 44, 65-76, https://doi.org/10.1007/s11243-018-0270-0.

14. Hussain, A.; AlAjmi, M.F.; Rehman, M.T.; Amir, S.; Husain, F.M.; Alsalme, A.; Siddiqui, M.A.; Al Khedhairy, A.A.; Khan, R.A. Copper (II) complexes as potential anticancer and Nonsteroidal anti- 
inflammatory agents: In vitro and in vivo studies. Scientific reports 2019, 9, 1-17, https://doi.org/10.1038/s41598-019-41063-x.

15. Wehbe, M.; Leung, A.W.; Abrams, M.J.; Orvig, C.; Bally, M.B. A Perspective-can copper complexes be developed as a novel class of therapeutics? Dalton Transactions 2017, 46, 10758-10773, https://doi.org/10.1039/C7DT01955F.

16. Gouda, A.M.; El-Ghamry, H.A.; Bawazeer, T.M.; Farghaly, T.A.; Abdalla, A.N.; Aslam, A. Antitumor activity of pyrrolizines and their $\mathrm{Cu}$ (II) complexes: design, synthesis and cytotoxic screening with potential apoptosis-inducing activity. European journal of medicinal chemistry 2018, 145, 350-359, https://doi.org/10.1016/j.ejmech.2018.01.009.

17. Fan, L.; Tian, M.; Liu, Y.; Deng, Y.; Liao, Z.; Xu, J. Salicylate• Phenanthroline copper (II) complex induces apo https://doi.org/ptosis in triple-negative breast cancer cells. Oncotarget 2017, 8, https://doi.org/10.18632/oncotarget.16161.

18. Ma, Z.Y.; Qiao, Z.; Wang, D.B.; Hou, X.; Qiao, X.; Xie, C.Z.; Qiang, Z.Y.; Xu, J.Y. A mixed-ligand copper (II) complex that inhibits growth and induces apoptosis by DNA targeting in human epithelial cervical cancer cells. Applied Organometallic Chemistry 2017, 31, https://doi.org/10.1002/aoc.3651.

19. Zhang, Y.-P.; Ma, Z.-Y.; Qiao, P.-P.; Gao, C.-Y.; Tian, J.-L.; Zhao, J.-Z.; Du, W.-J.; Xu, J.-Y.; Yan, S.-P. Design and biological evaluations of mono-and di-nuclear copper (II) complexes: Nuclease activity, cytotoxicity and apoptosis. Polyhedron 2011, 193, https://doi.org/10.1016/j.poly.2020.114880.

20. Chetana, P.; Srinatha, B.; Somashekar, M.; Policegoudra, R. Synthesis, spectroscopic characterisation, thermal analysis, DNA interaction and antibacterial activity of copper (I) complexes with N, N'-disubstituted thiourea. Journal of Molecular Structure 2016, 1106, 352-365, https://doi.org/10.1016/j.molstruc.2015.10.010.

21. Katugampala, S.; Perera, I.C.; Nanayakkara, C.; Perera, T. Synthesis, characterization, and antimicrobial activity of novel sulfonated copper-triazine complexes. Bioinorganic chemistry and applications 2018, 2018, https://doi.org/10.1155/2018/2530851.

22. Rajalakshmi, S.; Fathima, A.; Rao, J.R.; Nair, B.U. Antibacterial activity of copper (II) complexes against Staphylococcus aureus. RSC advances 2014, 4, 32004-32012, https://doi.org/10.1039/C4RA03241A.

23. Kumar, S.; Sindhu, J.; Choudhary, P.; Jaglan, S.; Zangrando, E.; Kumar, R.; Sahoo, S.C.; Kumar, V.; Mehta, S.K.; Kataria, R. Exploration of synthesis, structural aspects, DFT studies and bio-efficacy of some new DHA-benzohydrazide based copper (II) complexes. Journal of Molecular Structure 2020, https://doi.org/10.1016/j.molstruc.2020.129460.

24. Hooper, D.C.; Rubinstein, E. Quinolone antimicrobial agents. ASM Press Washington, DC, 2003.

25. Abdel-Aziz, A.A.-M.; El-Azab, A.S.; Alanazi, A.M.; Asiri, Y.A.; Al-Suwaidan, I.A.; Maarouf, A.R.; Ayyad, R.R.; Shawer, T.Z. Synthesis and potential antitumor activity of 7-(4-substituted piperazin-1-yl)-4oxoquinolines based on ciprofloxacin and norfloxacin scaffolds: in silico studies. Journal of Enzyme Inhibition and Medicinal Chemistry 2016, 31, 796-809, https://doi.org/10.3109/14756366.2015.1069288.

26. Verma, M.; Pandeya, S.N.; Singh, K.N.; Stables, J.P. Anticonvulsant activity of Schiff bases of isatin derivatives. Acta Pharmaceutica 2004, 54, 49-56.

27. Patel, M.N.; Bhatt, B.S.; Dosi, P.A. Spectroscopic study of DNA hydrolysis, DNA intercalative, and electrostatic interaction activity exerted by drug based coordination compounds. Zeitschrift für anorganische und allgemeine Chemie 2012, 638, 152-162, https://doi.org/10.1002/zaac.201100307.

28. Islam, M.R.; Islam, S.R.; Noman, A.S.M.; Khanam, J.A.; Ali, S.M.M.; Alam, S.; Lee, M.W. Biological screening of a novel nickel (II) tyrosine complex. Mycobiology 2007, 35, 25-29.

29. Patel, M.N.; Parmar, P.A.; Gandhi, D.S. Square pyramidal copper (II) complexes with forth generation fluoroquinolone and neutral bidentate ligand: structure, antibacterial, SOD mimic and DNA-interaction studies. Bioorganic \& medicinal chemistry 2010, 18, 1227-1235, https://doi.org/10.1016/j.bmc.2009.12.037.

30. Mazumder, U.K.; Gupta, M.; Karki, S.S.; Bhattacharya, S.; Rathinasamy, S.; Thangavel, S. Synthesis, anticancer and antibacterial activity of some novel mononuclear $\mathrm{Ru}$ (II) complexes. Chemical and pharmaceutical bulletin 2004, 52, 178-185, https://doi.org/10.1248/cpb.52.178.

31. $\mathrm{Wu}, \mathrm{C}$. An important player in brine shrimp lethality bioassay: The solvent. Journal of advanced pharmaceutical technology \& research 2014, 5, 57-58. 